\title{
EFEKTIVITAS PENERAPAN MODEL PEMBELAJARAN KOOPERATIF TIPE JIGSAW UNTUK MENINGKATKAN KEMAMPUAN PEMECAHAN MASALAH MATEMATIK SISWA KELAS VIII SMPN 14 KENDARI
}

\author{
La Ode Darwin. ${ }^{\text {() }}$, Lambertus ${ }^{2)}$,La Ndia ${ }^{3)}$ \\ ${ }^{1)}$ Alumni Jurusan Pendidikan Matematika, ${ }^{2,3)}$ Dosen Jurusan Pendidikan Matematika \\ FKIP Universitas Halu Oleo Email :laodedarwin24@gmail.com
}

\begin{abstract}
Abstrak
Penelitian ini dilatarbelakangi oleh rendahnya kemampuan pemecahan masalah matematik siswa. Populasi penelitian seluruh siswa kelasVIIISMPN 14 Kendari dengan sampel 2 kelas. Pengambilan sampel dengan teknik Random class sampling. Pengumpulan data dilakukan pemberian instrumen penelitian berupa lembar observasi dan tes kemampuan pemecahan masalah matematika. Berdasarkan hasil pembahasan diperoleh kesimpulan : (1) Model pembelajaran kooperatif Jigsaw kelas VIII SMPN 14 Kendari terkategori baik. (2) Kemampuan pemecahan masalah matematik kelas VIII $_{1}$ SMPN 14 Kendari yang diajar menggunakan model pembelajaran kooperatif Jigsaw padamateri kubus, balok,prisma dan limasterkategorisedang dengan rata-rata 71,92. (3) Kemampuan pemecahan masalah matematik siswa kelas VIII $_{4}$ SMPN 14 Kendari yang menggunakan modelpembelajaran konvensional pada materi kubus, balok,prisma dan limas terkategorikurang dengan rata-rata 57,60. (4) Modelpembelajaran kooperatif Jigsaw lebih efektifdibandingkan model pembelajaran konvensional pada materi kubus, balok,prisma dan limasdalam meningkatkan kemampuan pemecahan masalah matematik siswa kelas VIII SMPN14 Kendari.
\end{abstract}

Kata kunci: pembelajaran kooperatif, jigsaw, pemecahan masalah matematik

\section{EFFECTIVENESS OF APPLICATION OF TYPE OF JIGSAW COOPERATIVE LEARNING MODEL TO IMPROVE MATEMATIC PROBLEM SOLVING ABILITY OF CLASS VIII STUDENTS OF KENDARI 14 Junior High School}

\begin{abstract}
This research is motivated by the low ability of students to solve mathematical problem solving. The study population was all eighth grade students of SMP 14 Kendari with a sample of 2 classes. Sampling with Random class sampling technique. Data collection was carried out by giving research instruments in the form of observation sheets and tests of mathematical problem solving skills. Based on the results of the discussion obtained conclusions: (1) cooperative learning model of Jigsaw class VIII of SMPN 14 Kendari is categorized as good. (2) Mathematical problem solving ability of class VIII $_{1}$ of SMPN 14 Kendari which was taught using cooperative learning model Jigsaw on medium, average cubes, beams, prisms and limas with an average of 71.92. (3) Mathematical problem solving ability of class $\mathrm{VIII}_{4}$ SMPN 14 Kendari who use conventional learning models in the cube, beam, prism and limas are categorized less with an average of 57.60. (4)cooperative learning model is Jigsaw more effective than conventional learning models in cube, beam, prism and pyramid material in improving mathematical problem solving skills of VIII grade students of SMP 14 Kendari.
\end{abstract}

Keywords:cooperative learning model Jigsaw, students' mathematical problem solving ability. 


\section{Pendahuluan}

Pendidikan merupakan proses membantu manusia untuk meningkatkan harkat dan martabat manusia, sehingga mampu menghadapi setiap perubahan menuju arah yang lebih baik. Pendidikan sangatlah penting, mengingat pendidikan adalah pilar pembangunan sebuah bangsa. Mendasar pada hal tersebut negara berkewajiban menyediakan dan menyelenggarakan fasilitas serta meningkatkan kualitas pendidikan untuk mencetak generasi penerus bangsa yang berakhlak mulia, cerdas dan berkualitas.

$$
\text { Peningkatan mutu pendidikan }
$$

merupakan sasaran pokok pembangunan pendidikan. Upaya peningkatan mutu pendidikan adalah bagian terpadu dari upaya peningkatan kualitas manusia Indonesia, baik aspek kemampuan, kepribadian dan rasa tanggung jawab sebagai warga negara. Dalam UU Nomor 20 tahun 2003 tentang Sistem Pendidikan Nasional secara jelas dinyatakan bahwa pendidikan merupakan usaha sadar dan terencana untuk mewujudkan suasana belajar dan proses pembelajaran agar peserta didik secara aktif mengembangkan potensi dirinya untuk memiliki kekuatan spiritual agama, pengendalian diri, kepribadian, kecerdasan, akhlak mulia serta keterampilan yang diperlukan dirinya, masyarakat, bangsa dan negara.

Salah satu mata pelajaran yang perlu diajarkan kepada peserta didik adalah mata pelajaran matematika, mulai dari sekolah dasar sampai kejenjang pendidikan tinggi untuk membekali peserta didik dengan kemampuan berpikir logis, analitis, sistematis, kritis, dan kreatif, serta mampu memcahkan persoalanpersoalan atau permasalahan yang terjadi dalam kehidupan sehari-hari.

Pemecahan masalah adalah suatu proses untuk mengatasi kesulitan yang dihadapi untuk mencapai suatu tujuan yang hendak dicapai. Memecahkan suatu masalah itu bisa merupakan menyelesaikan soal cerita, menyelesaikan soal yang tidak rutin, mengaplikasikan matematika dalam kehidupan sehari-hari atau keadaan lain, dan membuktikan atau menciptakan atau menguji konjektur. Soal pemecahan masalah biasanya memuat suatu situasi yang dapat mendorong seseorang untuk menyelesaikannya akan tetapi anak tersebut tidak secara langsung dapat menyelesaikannya. Untuk dapat menyelesaikan soal pemecahan masalah dibutuhkan penalaran, pemahaman konsep dan keterampilan dalam matematika yang cukup tinggi.

Kemampuan pemecahan masalah matematik siswa juga telah menjadi fokus dalam pembelajaran matematika diberbagai Negara. Kemampuan siswa dalam pemecahan masalah dijadikan sentral dalam pengajaran matematika di Amerika Serikat sejak tahun 1980-an dan kemudian juga diberlakukan pada pembelajaran matematika sekolah dasar dan menengah di Singapura. Kemampuan pemecahan masalah merupakan hal yang sangat penting, bahkan NCTM (Nactional Council of Teacher of Mathematics) menegaskan bahwa kemampuan pemecahan masalah sebagai salah satu aspek penting dalam menjadikan siswa menjadi literat dalam matematika (Sugiman, 2009 : 5).

Pembelajaran pemecahan masalah dapat dipandang sebagai suatu proses dimana peserta didik menemukan perpaduan rumus/aturan/konsep yang sudah dipelajari sebelumnya, kemudian menerapkannya dalam rangka memperoleh pemecahan masalah dalam situassi dan kondisi yang baru. Cara tersebut merupakan proses belajar yang baru. Pembelajaran pemecahan masalah adalah jika peserta didik menemukan masalah dan peserta didik tersebut memiliki suatu obsesi/kehendak/keinginan yang sulit untuk diperoleh secara langsung.

Langkah pemecahan masalah dijelaskan oleh Polya (1) memahami masalah. Dalam hal ini siswa harus membaca soal cerita dengan cermat sehinga siswa dapat mengerti makna dari soal cerita, (2) membuat rencana penyelesaian. Dalam hal ini siswa merencanakan teori yang akan digunakan, (3) melaksanakan rencana. Dalam hal ini siswa menuliskan prosedur penyelesaian soal cerita, (4) memeriksa kembali. Dalam hal ini siswa memeriksa hasil akhirnya (Wardani, 2014 : 101- 102).

Tahapan pembelajaran pemecahan masalah sangat beragam antara pakar yang satu dengan pakar yang lainnya. Polya (1973) memberi empat langkah pokok dalam melaksanakan pembelajaran pemecahan masalah:

a) Memahami masalahnya. 
masing-masing peserta didik mengerjakan latihan yang berbeda dengan teman sebelahannya.

b) Menyusun Rencana Penyelesaian

Pada tahap ini peserta didik diarahkan untuk dapat mengidentifikasi masalah, kemudian mencari cara yang tepat untuk menyelesaikan masalah tersebut.

c) Melaksanakan Rencana Penyelesaian Tersebut

Pada tahap ini, peserta didik dapat menyelesaikan masalah dengan melihat contoh, dari buku, dan bertanya kepada guru.

d) Memeriksa Kembali Penyelesaian Yang Telah Dilaksanakan

Terakhir peserta didik mengulang kembali atau memeriksa jawaban yang telah dikerjakan, kemudian peserta didik bersama guru dapat menyimpulkan dan mempersentasikan didepan kelas.

Perkembangan dunia pendidikan seperti sekarang ini, guru dituntut agar tugas dan perannya tidak hanya sebagai sumber informasi, melainkan sebagai pendorong agar siswa belajar sehingga dapat mengkontruksi sendiri pengetahuannya melalui berbagai aktivitas seperti pemecahan masalah. Namun sebagian besar guru masih menerapkan pebelajaran yang bersifat konvensional yang pada saat pelaksanaannya dimulai dari menjelaskan materi, memberi contoh dan dilanjutkan dengan latihan soal, sehingga pembelajaran cenderung didominasi oleh guru. Siswa kurang diberikan kesempatan untuk memikirkan dan menemukan konsep sendiri. Hal ini menyebabkan konsep yang dipelajari siswa cendeung tidak bertahan lama atau mudah hilang bahkan kadang-kadang siswa tidak mengerti atau tidak memahami sama sekali konsep yang sedang dipelajari.

Dominasi guru dalam kelas menyebabkan siswa menjadi pasif karena siswa kurang dapat mengemukakan ide-ide dan pendapat yang dimilikinya. Siswa juga masih enggan untuk bertanya kepada guru atau bertanya kepada temannya meskipun siswa itu tidak dapat memecahkan masalah yang diberikan oleh guru. Penggunaan model pembelajaran yang tepat merupakan solusi yang sangat membantu dalam peningkatan hasil belajar siswa serta partisipasi siswa secara aktif dalam proses pembelajaran.

Pembelajaran matematika jika berhasil akan menghasilkan siswa yang memiliki kemampuan pemecahan masalah, kemampuan komunikasi, kemampuan penalaran, kemampuan pemahaman dan kemampuan yang lain dengan baik, serta mampu memanfaatkan kegunaan matematika dalam kehidupan. Namun kenyataannya kemampuan pemecahan masalah matematik siswa masih jauh dari harapan. Keterampilan menyelesaikan soal pemecahan masalah siswa sekolah menengah atas maupun siswa sekolah menengah pertama masih rendah. Sejalan dengan hasil penelitian Fakhrudin (2010) terhadap sekolah menengah pertama secara umum hasil kemampuan tentang pemecahan masalah matematik siswa SMP belum memuaskan sekitar 30,67\% dari skor ideal (Anisa, $2014:$ 2)

Aktivitas pembelajaran kooperatif menekankan pada kesadaran siswa perlu belajar untuk mengaplikasikan pengetahuan, konsep, keterampilan kepada siswa yang membutuhkan atau anggota lain dalam kelompoknya, sehingga belajar kooperatif dapat menguntungkan antara siswa yang memiliki kemampuan rendah, sedang, dan tinggi. Dalam hal ini pembelajaran kooperatif dimaksudkan agar siswa benar-benar menerima ilmu dari pengalaman belajar bersama teman-temannya baik yang sudah cakap maupun yang masih dikatakan kurang dalam memahami konsep atau materi yang dipelajari. Pembelajaran kooperatif merupakan model pembelajaran yang mengutamakan adanya kerja sama antara siswa dalam kelompok untuk mencapai keberhasilan dalam mencapai tujuan pendidikan.

Model pembelajaran kooperatif dipandang sebagai proses pembelajaran yang aktif. Sebab peserta didik akan lebih banyak belajar melalui proses pembentukan dan penciptaan kerjasama dalam kelompok dan berbagai pengetahuan serta tanggungjawab individu tetap merupakan kunci keberhasilan pembelajaran. Pembelajaran kooperatif sesuai dengan fitrah manusia sebagai makhluk sosial yang penuh ketergantungan dengan orang lain, mempunyai tujuan dan tangung jawab bersama, pembagian tugas dan rasa senasib.Pembelajaran kooperatif yang dianggap dapat memotivasi siswa untuk berperan aktif dan bertanggung jawab dalam menyelesaikan masalah yang diberikan dalam proses belajar-mengajar adalah model pembelajaran kooperatif tipe Jigsaw. Model pembelajaran kooperatif tipe Jigsaw adalah sebuah teknik pembelajaran kooperatif dimana siswa memiliki tanggung jawab lebih 
besar dalam pelaksanaan pembelajaran. Adapun tujuan dari model pembelajaran ini adalah untuk mengembangkan kerja sama tim dalam menguasai pengetahuan secara mendalam yang tidak mungkin diperoleh bila mereka mencoba untuk mempelajari semua materi sendiri.

Pembelajaran model ini lebih meningkatkan kerja sama antar siswa. Siswasiswa terbagi dalam beberapa kelompok belajar dan bekerja sama dalam suatu perencanaan kegiatan. Jigsaw didesain untuk meningkatkan rasa tanggung jawab siswa terhadap pembelajarannya sendiri dan juga pembelajaran orang lain, sehingga dengan model ini siswa akan lebih mudah memecahkan masalah matematika dan diharapkan dapat meningkatkan hasil belajar matematika.

Pembelajaran kooperatif adalah salah satu bentuk pembelajaran yang berdasarkan faham konstruktivis. Pembelajaran kooperatif merupakan strategi belajar dengan sejumlah siswa sebagai anggota kelompok kecil yang tingkat kemampuannya berbeda. Pembelajaran kooperatif sesuai dengan fitrah manusia sebagai mahluk sosial yang penuh ketergantungan dengan orang lain, mempunyai tujuan dan tanggung jawab bersama, pembagian tugas dan rasa senasib. Dengan memanfaatkan kenyataan itu, belajar berkelompok secara kooperatif, siswa dilatih dan dibiasakan untuk saling berbagi (sharing) pengetahuan, pengalaman, tugas, dan tanggung jawab (Ngalimun, 2012 : 161).

Model pembelajaran kooperatif diyakini dapat memberi peluang peserta didik untuk terlibat dalam diskusi, berpikir kritis, berani, dan mau mengambil tanggung jawab untuk pembelajaran mereka sendiri. Meskipun model pembelajaran kooperatif mengutamakan peran aktif peserta didik, bukan berarti pengajar tidak berpartisipasi. Sebab, dalam proses pembelajaran, pengajar berperan sebagai perancang, fasilitator, dan pembimbing dalam proses pembelajaran (Daryanto, 2013 : 401).

Model pembelajaran kooperatif tipe Jigsaw menitikberatkan kepada kerja kelompok dalam bentuk kelompok kecil. Model Jigsaw ini merupakan model belajar kooperatif dengan cara siswa belajar dalam kelompok kecil yang terdiri atas $3-5$ orang secara heterogen. Siswa bekerjasama saling ketergantungan positif dan bertanggung jawab secara mandiri. Dalam model pembelajaran Jigsaw, siswa banyak memiliki kesempatan untuk mengemukakan pendapat dan mengolah informasi yang didapat dan dapat meningkatkan keterampilan berkomunikasi. Anggota kelompok bertanggung jawab atas keberhasilan kelompoknya dan ketuntasan bagian materi yang dipelajari dan dapat menyampaikan kepada kelompoknya (Shoim, 2013 : 90).

Dengan demikian, model pembelajaran ini sangat penting dalam proses belajar mengajar di kelas. Tugas sebagai seorang guru harus mampu menentukan pendekatan, model dan metode pembelajaran yang tepat sesuai dengan materi yang akan disampaikan agar dapat menciptakan suasana pembelajaran aktif sehingga mudah dipahami oleh siswa. Selain itu, metode penyampaian harus jelas dan tidak bertele-tele agar mudah diterima dan dipahami oleh siswa. Menurut Dr. M.Sobry Sutikno dalam bukunya tentang metode dan modelmodel pembelajaran bahwa " Dalam mendidik anak, tidak cukup bagi seorang guru hanya dengan menguasai materi pembelajaran saja, tetapi ia juga harus menguasai metode penyampaiannya". Berdasarkan pernyataan beliau, patut dijadikan sebagai pelajaran berharga bagi guru agar mempersiapkan diri secara matang baik faktor internal maupun eksternal sebelum melaksanakan proses belajar mengajar.

Model pembelajaran kooperatif tipe Jigsaw memberikan kesempatan kepada siswa untuk dapat melakukan kerja sama dengan anggota kelompoknya dalam menghadapi segala persoalan yang dihadapi. Dalam pembelajaran kooperatif tipe Jigsaw siswa didorong lebih aktif dan setiap pembelajaran yang dilakukannyapun akan lebih bermakna. Selain itu juga siswa bekerja dengan sesama siswa dalam suasana gotong royong dan mempunyai banyak kesempatan untuk mengolah informasi dan meningkatkan keterampilan berkomunikasi (Abidin, 2013 : 256).

Model pembelajaran kooperatif tipe Jigsaw juga di desain untuk meningkatkan rasa tanggung jawab siswa terhadap pembelajarannya sendiri dan juga pembelajaran orang lain. Siswa tidak hanya mempelajari materi yang diberikan, tetapi mereka juga harus memberikan dan mengajarkan materi tersebut kepada kelompoknya. Pada model pembelajaran Jigsaw ini keaktifan siswa sangat dibutuhkan, dengan dibentuknya kelompok-kelompok kecil 
yang beranggotakan 3-5 orang yang heterogen, yang terdiri dari kelompok asal dan kelompok ahli. Kunci tipe Jigsawini adalah interdepence setiap siswa terhadap anggota tim yang memberikan informasi yang diperlukan. Artinya para siswa harus memiliki tanggung jawab dan kerja sama yang positif dan saling ketergatungan untuk mendapatkan informasi dan memecahkan masalah yang diberikan (Kurniasih, $2015: 24$ ).

Berdasarkan uraian diatas, secara umum pembelajaran kooperatif tipe Jigsaw dapat melibatkan siswa secara aktif dalam

Tabel 1.

mengembangkan pengetahuan, sikap, dan keterampilannya dalam suasana pembelajaran yang bersifat terbuka dan demokratis. Selain itu, siswa dilatih untuk saling berkerja sama dalam kelompoknya, sehingga mampu menumbuhkan rasa tanggung jawab siswa dalam memahami dan menyelesaikan secara kelompok.

Berikut sintaks model pembelajaran koopertaif tipe jigsaw dapat disajikan pada Tabel

\begin{tabular}{|l|l|}
\hline \multicolumn{1}{|c|}{ Fase } & \multicolumn{1}{c|}{ Kegiatan Guru } \\
\hline $\begin{array}{l}\text { Fase 1 } \\
\text { Menyampaikan tujuan, } \\
\text { memotivasi siswa dan memberi } \\
\text { apersepsi }\end{array}$ & $\begin{array}{l}\text { Guru menyampaikan tujuan pembelajaran yang ingin } \\
\text { dicapai, memotivasi siswa belajar dan memberi apersepsi }\end{array}$ \\
\hline $\begin{array}{l}\text { Fase 2 } \\
\text { Menyajikan informasi }\end{array}$ & $\begin{array}{l}\text { Guru menyajikan informasi yang berkaitan dengan } \\
\text { materi pelajaran dengan jalan demonstrasi atau lewat } \\
\text { bahan bacaan }\end{array}$ \\
\hline $\begin{array}{l}\text { Fase 3 } \\
\text { dalam kelompok }\end{array}$ & $\begin{array}{l}\text { Guru menjelaskan cara membagi kelompok dan cara } \\
\text { kerja kelompok asal dan kelompok ahli }\end{array}$ \\
\hline $\begin{array}{l}\text { Fase 4 } \\
\text { Memberikan masalah } \\
\text { tugas/soal }\end{array}$ & $\begin{array}{l}\text { Guru memberikan masalah/tugas/soal untuk dibahas } \\
\text { dalam kelompok asal dan kelompok ahli. }\end{array}$ \\
\hline $\begin{array}{l}\text { Fase 5 } \\
\text { Membimbing kelompok } \\
\text { bekerja dan belajar }\end{array}$ & $\begin{array}{l}\text { Guru membimbing kelompok-kelompok belajar pada } \\
\text { kelompok ahli dan kelompok asal }\end{array}$ \\
\hline $\begin{array}{l}\text { Fase 6 } \\
\text { Evaluasi }\end{array}$ & $\begin{array}{l}\text { Guru mengevaluasi hasil belajar tentang materi yang } \\
\text { telah dipelajari }\end{array}$ \\
\hline $\begin{array}{l}\text { Fase 7 } \\
\text { Memberi penghargaan }\end{array}$ & $\begin{array}{l}\text { Guru memberikan penghargaan baik pada kelompok } \\
\text { maupun individu. }\end{array}$ \\
\hline
\end{tabular}

(Nurhadi, 2003 : 64).

Keterlibatan guru sebagai pusat kegiatan kelas dalam proses pembelajaran dengan menggunakan pembelajaran kooperatif tipe jigsaw ini semakin berkurang. Guru hanya sebagai fasilitator yang mengarahkan dan memotivasi siswa untuk belajar mandiri dan mengembangkan potensi yang dimilikinya sendiri, karena dalam kegiatan pembelajaran siswa tidak hanya sebagai objek belajar melainkan juga sebagai subjek belajar sehingga setiap siswa dapat menjadi tutor sebaya bagi siswa lainnya. Adapun ilustrasi model pembelajaran kooperatif tipe Jigsawdapat dilihat pada gambar 1 berikut (Abidin, 2014 : 257). 


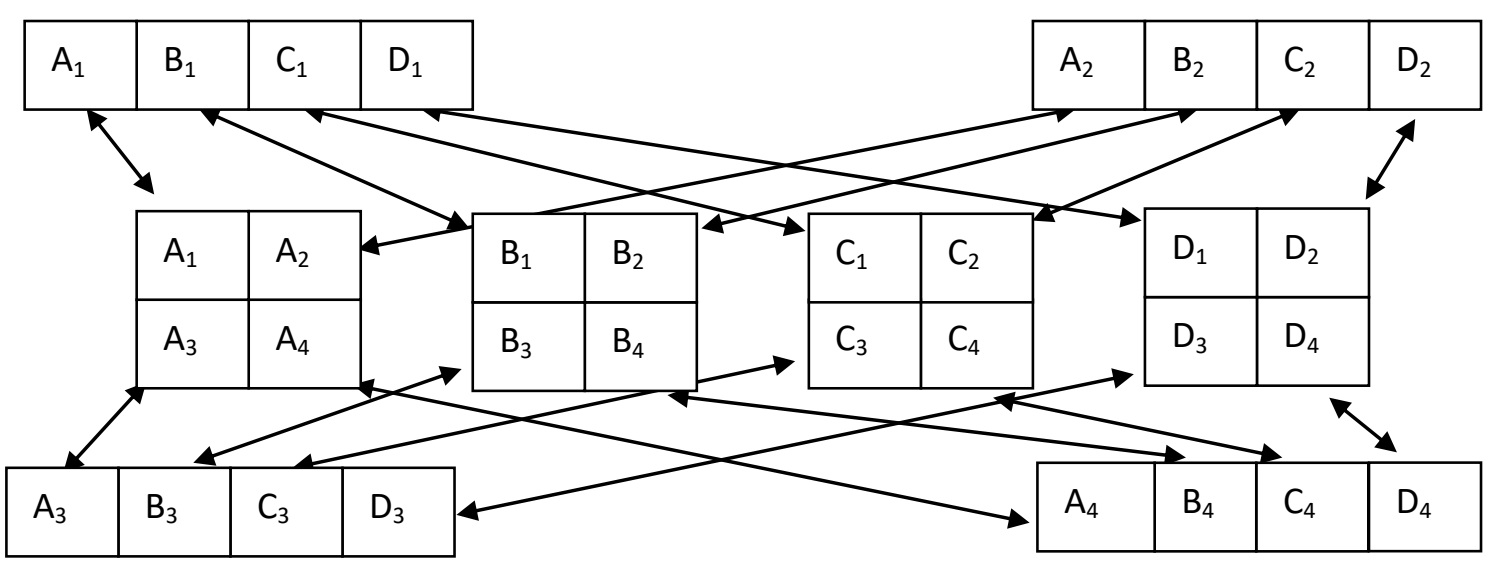

Gambar 1. Ilustrasi model pembelajaran kooperatif tipeJigsaw

kooperatif

Dengandemikianmodel pembelajaran

Jigsawmemungkinkandigunakanuntuk

meningkatkan kemampuan siswadalam pemecahan masalahmatematik.

Berdasarkan uraian di atas maka penulis bermaksud untuk melakukan penelitian berjudul "Efektivitas Penerapan model pembelajaran kooperatif tipe Jigsaw untuk meningkatlan Kemampuan Pemecahan Masalah Matematik Siswa Kelas VIII SMPN 14 Kendari”.

\section{Metode}

Jenis penelitian ini adalah penelitian ekspeimen semu dengan menggunakan model pembelajaran kooperatif tipe Jigsaw. Teknik pengambilan sampel dilakukan secara Random class sampling, yaitu dengan mengambil dua kelas secara acak. Dari cara tersebut diperoleh kelas $\mathrm{VIII}_{1}$ dan kelas $\mathrm{VIII}_{4}$ sebagai sampel. Penentuan kelas yang akan diajar dengan model pembelajaran kooperatif tipe Jigsaw dan pembelajaran konvensional juga dilakukan secara random, dari hasil proses pengacakan diperoleh kelas $\mathrm{VIII}_{1}$ sebagai kelas eksperimen yang diajar dengan model pembelajaran kooperatif tipe Jigsaw dan kelas $\mathrm{VIII}_{4}$ sebagai kelas kontrol yang diajar dengan model pembelajaran konvensional.

Variabel dalam penelitian ini terdiri dari variabel bebas yaitu perlakuan berupa pembelajaran dengan menggunakan model pembelajaran kooperatif tipe Jigsaw pada kelas eksperimen dan perlakuan berupa modelpembelajaran konseptual (konvensional) pada kelas kontrol dan variabel terikat yaitu kemampuan pemecahan masalah matematik siswa yang diajar dengan menggunakan model pembelajaran kooperatif tipe Jigsawdan kemampuan pemecahan masalah matematik siswa yang diajar dengan model pembelajaran konvensional. Desain penelitiannya ditunjukkan pada Tabel 2.

Tabel2

Gambaran Desain Penelitian

\begin{tabular}{|l|c|c|c|}
\hline Kelompok & Pretest & Perlakuan & Posttest \\
\hline Eksperimen & $\mathrm{T}_{1}$ & $\mathrm{X}_{1}$ & $\mathrm{~T}_{3}$ \\
\hline Kontrol & $\mathrm{T}_{2}$ & $\mathrm{X}_{2}$ & $\mathrm{~T}_{4}$ \\
\hline
\end{tabular}

(Sugiyono, $2015: 13$ )

Dimana :

$\mathrm{T}_{1}=$ Pretest sebelum perlakuan pada kelas eksperimen.

$\mathrm{T}_{2}=$ Pretest sebelum perlekuan pada kelas kontrol.
$\mathrm{T}_{3}=$ Hasil Posttest siswa pada kelas eksperimen.

$\mathrm{T}_{4}=$ Hasil Posttest siswa pada kelas kontrol.

$\mathrm{X}_{1}=$ Perlakuan berupa model pembelajaran kooperatif tipe Jigsaw 
$\mathrm{X}_{2}=$ Perlakuan berupa model pembelajaran konvensional

Uji validitas dan reliabilitas instrumen penelitian yang dilakukan pada penelitian ini adalah uji panelis. Validitas penilaian panelis digunakan untuk mengetahui validitas konsep instrument apakah layak di gunakan untuk mengukur kemampuan pemecahan masalah matematik siswa atau tidak sedangkan uji reliabiltas tes yang dilakukan terhadap soal yang terpilih, menggunakan rumus Alpha sebagai berikut:

$$
r_{11}=\left(\frac{k}{k-1}\right)\left(1-\frac{\sum \sigma_{b}^{2}}{\sigma_{t}^{2}}\right)
$$

Keterangan:

$\mathrm{r}_{1}=$ reliabilitas instrumen

$\mathrm{k}=$ banyaknya butir pertanyaan atau banyaknya soal

$\Sigma \sigma_{b}^{2}=$ jumlah varians butir

$\sigma_{t}^{2}=$ varians total

Penelitian ini dilakukanlah pengujian hipotesis (uji-t) dengan terlebih dahulu dilakukan uji syarat normalitas dan homogenitas data. Rumus uji-t yang digunakan adalah:

$$
\mathrm{t}_{\text {hitung }}=\frac{\overline{\mathrm{Y}}_{1}-\overline{\mathrm{Y}}_{2}}{\mathrm{~S}_{\mathrm{g}} \sqrt{\frac{1}{n_{1}}+\frac{1}{n_{2}}}}
$$

Untuk mendapatkan nilai simpangan baku

gabungan digunakan rumus:

$$
S_{g}=\sqrt{\frac{\left(n_{1}-1\right) S_{1}^{2}+\left(n_{2}-1\right) S_{2}^{2}}{n_{1}+n_{2}-2}}
$$

(Sudjana, 2002: 239)

Keterangan:

$\mathrm{t}_{\text {hitung }}=$ Nilai hitung untuk uji- $\mathrm{t}$

$\overline{\mathrm{Y}}_{1} \quad=$ Rata-rataKPMM kelas eksperimen

$\overline{\mathrm{Y}}_{2} \quad$ = Rata-rata KPMM kelas kontrol

$\mathrm{n}_{1} \quad=$ Jumlah subyek kelas eksperimen

$\mathrm{n}_{2} \quad=$ Jumlah responden kelas kontrol

$\mathrm{S}_{\mathrm{g}} \quad=$ Simpangan baku gabungan

$\mathrm{S}_{1}^{2}=$ Varians data sampel kelas eksperimen

$\mathrm{S}_{2}^{2} \quad=$ Varians data sampel kelas kontrol

Dengan kriteria pengujian sebagai berikut:
Terima $\mathrm{H}_{0}$ jika $t_{\text {hitung }}<t_{\left(1-\alpha, n_{1}+n_{2}-2\right)}$, untuk harga-harga $t$ yang lainnya $\mathrm{H}_{0}$ ditolak.

Hasil

Hasil analisis instrumen pretest kemampuan pemecahan masalah matematik terdiri dari analisis validitas dan analisis reliabilitas yang didasarkan pada hasil 3 orang panelis. adapun hasil analisis validitas pretest kemampuan pemecahan masalah matemati yang terdiri dari 6 soal berbentuk essay diperoleh bahwa semua soal pretest valid. Sedangkan untuk hasil analisis reliabilitas pretest kemampuan pemecahan masalah matematik siswa diperoleh koefisien reliabilitasnya sebesar 0,736 yang dapat diinterpretasikan dalam kategori tinggi. hal ini berarti bahwa tes ini cukup diandalkan untuk mengukur kemampuan pemecahan masalah matematik siswa. hasil analisis instrumen post test kemampuan pemecahan masalah matematik terdiri dari analisis validitas dan analisis reliabilitas yang didasarkan pada hasil 3 ornag panelis yang terdiri dari 2 guru matematika dan 1 dosen pendidikan matematika. adapun hasil analisis validitas pretest kemampuan pemecahan masalah matemati yang terdiri dari 6 soal berbentuk essay diperoleh bahwa semua soal pretest valid. Sedangkan untuk hasil analisis reliabilitas pos test kemampuan pemecahan masalah matematik siswadiperoleh koefisien reliabilitasnya sebesar 0,702 yang dapat diinterpretasikan dalam kategori tinggi. Hal ini berarti bahwa tes ini cukup diandalkan untuk mengukur kemampuan pemecahan masalah matematik siswa.Berdasarkan hasil observasi terhadap pelaksanaan pembelajaran matematika dengan menggunakan model 
pembelajaran kooperatif tipe Jigsaw oleh guru di kelas eksperimen pada materi kubus, balok, prisma dan limas, keberhasilan pengelolaan pembelajaran pada 8pertemuan sudah baik. Tingkat keberhasilan secara berturut turut sebesar $76,92 \%, 92,30 \%, 84,61 \%, 76,92 \%$, $84,61 \%, 84,615,92,30 \%$ dan $92,30 \%$.

Berdasarkan hasil observasi aktivitas siswa dalam pelaksanaan pembelajaran matematika menggunakan model pembelajaran kooperatif tipe Jigsawdi kelas eksperimen pada materi kubus, balok,prisma dan limas pada 8pertemuan, ketercapaian seluruh aspek yang diamati adalah $81,81 \%, 81,81 \%, \quad 75,94 \%$, $75,00 \%, 77,27 \%, 79,54 \%, 86,36 \%$ dan $86,36 \%$ Persentase ini menunjukkan tingkat keaktifan siswa yang diajar dengan menggunakan model pembelajaran kooperatif tipe Jigsaw sudah terintrepertasi baik.

Ukuran statistik data diperoleh dari analisis data hasil tes kemampuan pemecahan masalah matematik yang dilaksanakan terhadap kelas eksperimen dan kelas kontrol. Penentuan kelas eksperimen dan kelas kontrol dilakukan secara purposive seperti yang telah dikemukakan pada bab III. Kelas eskperimen yaitu kelas VIII $_{1}$ dengan jumlah siswa 25 orang, dan kelas kontrol yaitu kelas $\mathrm{VIII}_{4}$ dengan jumlah siswa 25 orang. Berdasarkan hasil analisis deskriptif dengan olahan Microsoft Excel 2007 diperoleh data kemampuan pemecahan masalah matematik kelas eksperimen dan kontrol yang disajikan pada Tabel 3.

Tabel 3

Statistik Deskriptif Kemampuan pemecahan masalah matematis Siswa Kelas Eksperimen dan Kelas Kontrol

\begin{tabular}{|c|c|c|}
\hline Statistik Deskriptif & Kelas Eksperimen & Kelas Kontrol \\
\hline Rata-rata & 71,92 & 57,60 \\
\hline $\mathrm{N}$ & 25 & 25 \\
\hline Standar deviasi & 10,02 & 9,20 \\
\hline Varians Sampel & 100,49 & 84,67 \\
\hline Nilai Maksimum & 84 & 34 \\
\hline Nilai Minimum & 34 & 52 \\
\hline Modus & 70 & 58 \\
\hline Median & 74 & \\
\hline
\end{tabular}

Hasil analisis deskriptif pada kelas eksperimen sebagaimana disajikan pada tabel di atas diperoleh nilai terrendah 34 dan nilai tertinggi 84 , nilai rata-rata 71,92 , median atau nilai tengah 74 , modus atau nilai yang sering muncul yaitu 70 , standar deviasi 10,02 dan varians 100,49

Seperti yang telah dikemukakan sebelumnya, bahwa tujuan penelitian ini adalah Untuk mengetahui proses pembelajaran dengan model pembelajaran koopertaif tipe
Jigsaw pada siswa kelas VIII SMPN 14 Kendari,Untuk mengetahui deskripsikemampuan pemecahan masalah matematika Siswa kelas VIII SMPN 14 Kendari yang diajar dengan menggunakan model pembelajaran koopertaif tipe Jigsaw,Untuk mengetahui deskripsikemampuan pemecahan masalah matematik siswa kelas VIII SMPN 14 Kendari yang diajar dengan model pembelajaran konvensional, serta Untuk 
mengetahui apakah model pembelajaran koopertaif tipe Jigsawlebih efektif daripada model pembelajaran konvensionaluntuk meningkatkan kemampuan pemecahan masalah matematiksiswa kelas VIII SMPN 14 Kendari.

Uji normalitas digunakan untuk mengetahui apakah data kemampuan pemecahan masalah matematik kedua kelas berdistribusi normal atau tidak digunakan statistik Kolmogorof-Smirnov , dengan menggunakan bantuan aplikasi SPSS. Hasil perhitungan dapat disajikan dalam tabel 4.

Tabel 4

Hasil Analisis Statistik Uji Normalitas Data

Kemampuan Pemecahan Masalah Matematis Siswa pada Kelas Eksperimen

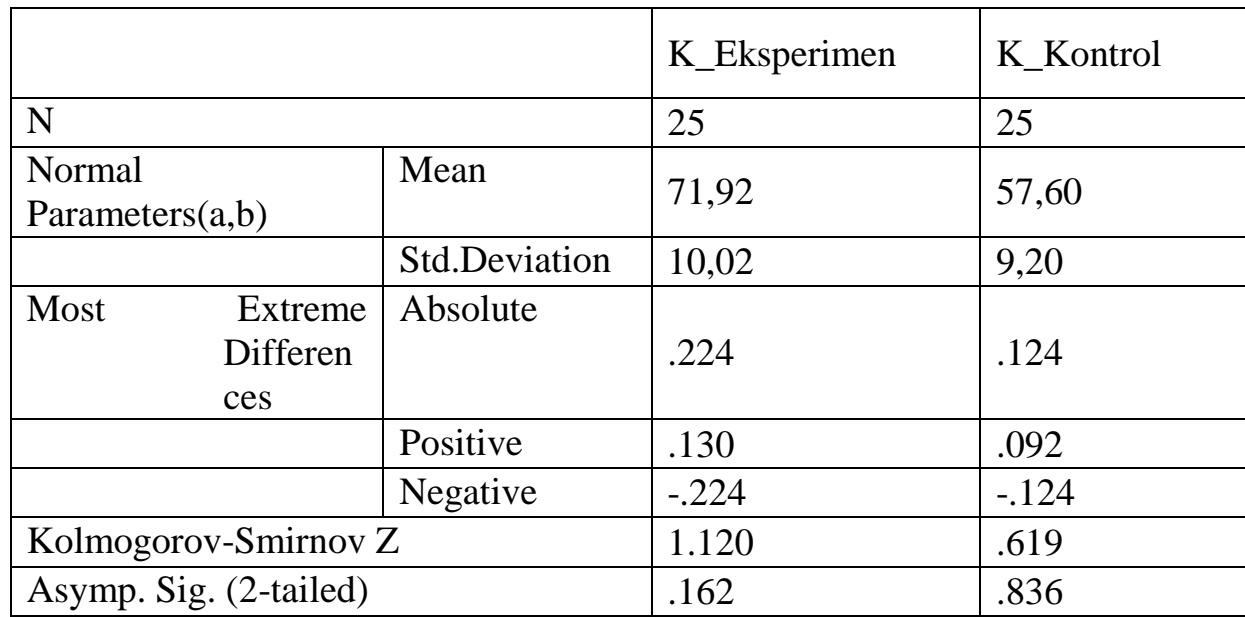

a Test distribution is Normal.

b Calculated from data.

Pada Tabel 6 di atas dapat dilihat bahwa nilai Asymp. Sig. (2-tailed) untuk kelas eksperimen adalah $0,162>\alpha$ (dengan $\alpha=0,05$ ), sehingga $\mathrm{H}_{0}$ diterima. Dengan demikian, dapat disimpulkan bahwa data kemampuan pemecahan masalah matematik siswa kelas eksperimen berdistribusi normal. Sedangkan untuk kelas kontrol, terlihat bahwa nilai Asymp. Sig. (2-tailed)nya adalah $0,839>\alpha$ (dengan $\alpha=$
0,05), sehingga $\mathrm{H}_{0}$ diterima. Dengan demikian, dapat disimpulkan bahwa data kemampuan pemecahan masalah matematik siswa pada kelas kontrol berdistribusi normal.

Uji homogenitas digunakan untuk mengetahui apakah data mempunyai varians yang sama (homogen) atau tidak. Untuk menguji apakah data mempunyai varians yang sama atau tidak digunakan statistik uji $\mathrm{F}$ dengan menggunakan program microsoft excel seperti yang disajikan pada Tabel 5 berikut:

Tabel 5

Hasil Analisis Statistik Uji Homogenitas Data

Kemampuan Berpikir Kreatif Matematik Siswa

\begin{tabular}{|c|c|}
\hline Ukuran Statistik & Nilai \\
\hline Varians Kelas Eksperimen & 100,493 \\
\hline Varians Kelas Kontrol & 84,67 \\
\hline F Hitung & 1,186 \\
\hline F Tabel & 1,98 \\
\hline Kesimpulan & Homogen \\
\hline
\end{tabular}


Dari Tabel 5, terlihat bahwa nilai dari $\mathrm{F}_{\text {hitung }}<\mathrm{F}_{\text {tabel }}$ maka $\mathrm{H}_{0}$ diterima. Sehingga dapat disimpulkan bahwa kedua kelompok memiliki varians yang relatif sama. Ini berarti sebaran kedua kelompok yaitu yang menggunakanmodel pembelajaran kooperatif tipe Jigsaw dan model pembelajaran konvensional memiliki varians homogen. Data yang diperoleh berdistribusi normal, dan memiliki varians yang homogen, maka untuk menguji tes kemampuan pemecahan masalah matematik siswa yang diajar dengan menggunakan model pembelajaran kooperatif tipe Jigsawdan siswa yang diajar denganmodel pembelajaran konvensional, digunakan uji one sample $t$ test. Rumus hipotesis statistik yang diuji adalah :

Keterangan :

$$
\mathrm{H}_{0}: \mu_{1} \leq \mu_{2} \quad \text { lawan } \mathrm{H}_{1}: \mu_{1}>\mu_{2}
$$

$\mathrm{H}_{0}=$ model pembelajaran kooperatif tipe

Jigsaw tidak lebih baik dibanding model pembelajaran konvensional untuk meningkatkan kemampuan pemecahan masalah matematik

$\mathrm{H}_{1}=$ model pembelajaran kooperatif tipe Jigsaw lebih baik dibandingkan dengan model pembelajaran konvensional untuk meningkatkan kemampuan pemecahan masalah matematik

$\mu_{1}=$ Rata-rata kemampuan pemecahan masalah matematik siswa yang diajar dengan model pembelajaran kooperatif tipe Jigsaw.

$\mu_{2}=$ Rata-rata kemampuan pemecahan masalah matematik siswa yang diajar dengan model pembelajaran konvensional.

Hasil pengujian hipotesis dapat dilihat pada Tabel 6 berikut ini.

Tabel 6

Hasil Analisis Statistik Uji-t dua sampel independen

TestKemampuan Pemecahan Masalah Matematis

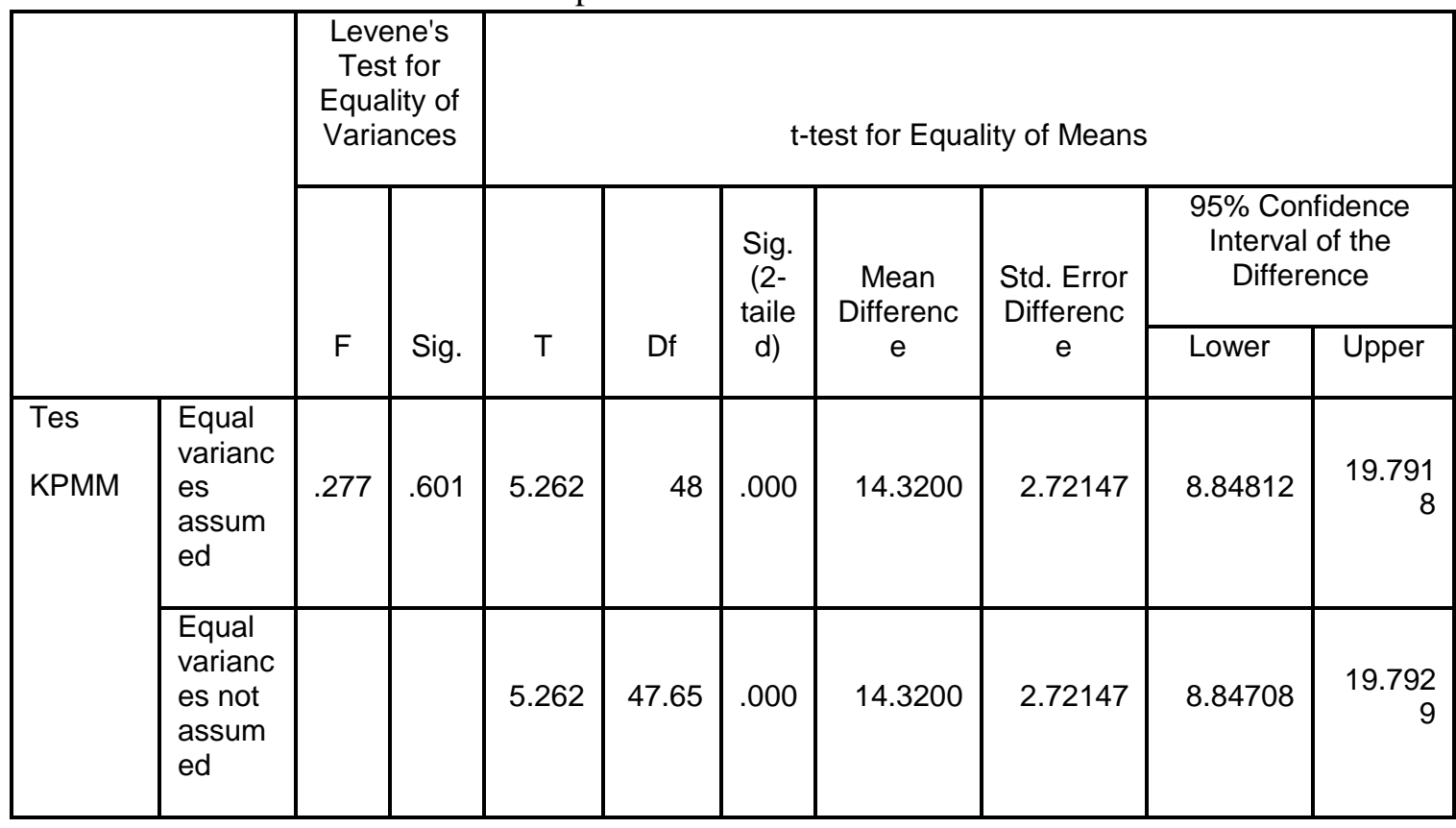

BerdasarkanTabel 9 di atas, terlihat bahwa nilai sig. (2-tailed) untuk asumsi varians yang sama lebih kecil dari $\propto=0,05 \quad(0,00>\propto=0,05)$, sehingga $\mathrm{H}_{0}$ ditolak. Karena $\mathrm{H}_{0}$ ditolak, maka dapat disimpulkan model pembelajaran kooperatif tipe Jigsaw lebih baik dibandingkan dengan model pembelajaran konvensional dalam meningkatkan kemampuan pemecahan masalah matematik siswa.

\section{Pembahasan}

Jenis penelitian ini adalah penelitian eksperimen tentang efektivitas penerapan modelpembelajaran kooperatif tipe Jigsaw untuk 
meningkatkankemampuan pemecahan masalah matematik siswa pada materi kubus, balok,prisma dan limas kelas VIII SMP Negeri 14 Kendari. Penelitian ini mulai dilaksanakan pada tanggal 8 Maret 2017 sampai tanggal 24 Mei 2017. Waktu pembelajaran dalam pelaksanaan penelitian antara kelas eksperimen dan kelas kontrol berturut-turut adalah 11 dan 10 jam pelajaran..

Dalam penelitian ini menggunakan dua kelas sebagai kelas eksperimen dan kelas kontrol. Kelas eksperimen mengunakan model pembelajaran kooperatif tipe Jigsaw, sedangkan kelas kontrol menggunakan model pembelajaran konvensional. Pada kedua kelas, siswa diberi pretest sebelum proses pembelajaran dilaksanakan, kemudian diberi posttest setelah pembelajaran selesai dilaksanakan

Total pertemuan dalam penelitian ini yaitu sebanyak sepuluh kali pertemuan, dengan delapan kali pertemuan digunakan untuk proses pembelajaran, dan dua kali pertemuan digunakan untuk tes kemampuan kemampuan pemecahan masalah matematik siswa yakni, pretest dan posttest pada masing-masing kelas. Selain itu, kedua kelas juga diberi materi yang sama dengan urutan yang sama. Pembelajaran yang dilaksanakan pada kelas eksperimen adalah model pembelajaran kooperatif tipe Jigsaw, yang memiliki empat tahap pembelajaran yaitu, pengelompokan siswa kedalam kelompokkelompok kecil yang heterogen, pemberian tugas atau masalah, masing-masing perwakilan kelompok kembali ke kelompok asalnya untuk menjelaskan pada teman kelompoknya, dan tahap akhir Pada tahap pengelompkan siswa, merupakan tahap awal dimana guru mengelompokan siswa kedalam kelompokkelompok kecil yang heterogen,pemberian tugas atau masalah, masing-masing perwakilan kelompok ke kelompok asalnya untuk menjelaskan pada teman kelompoknya, dan tahap akhir pemberian tes atau kuis oleh guru.

Pada tahap pengelompkan siswa, merupakan tahap awal dimana guru mengelompokan siswa kedalam kelompokkelompok kecil yang heterogen. Pembentukan kelompok-kelompok siswa tersebut dapat dilakukan oleh guru berdasarkan pertimbangan tertentu, seperti kemampuan akademis siswa maupun karakteristik lainnya.

Tahap pemberian tugas atau masalah, setelah siswa dikelompokan menjadi beberapa kelompok, pada model pembelajaran koopertaif tipe Jigsaw ini setiap anggota kelompok diberi tugas untuk mempelajari suatu masalah tertentu. Kemudian siswa-siswi atau perwakilan kelompok masing-masing yang mempelajari suatu masalah ang sama bertemu dengan anggota dari kelompok lain dalam kelompok ahli. Masalah tersebut didiskusikan sehingga masing-masing perwakilan tersebut dapat memahami dan menguasai materi atau permasalahan yang diberikan.

Selanjutnya, pada tahap ketiga masingmasing perwakilan kelompok kembali ke kelompok asalnya untuk menjelaskan pada teman satu kelompoknya mengenai masalah yang telah didiskusikan pada kelompok ahli, sehingga semua anggota kelompoknya dapat masalah yang diberikan oleh guru.

Pada pertemuan di kelas eksperimen pertama-tama dilakukan kegiatan pendahuluan, yang meliputi pemberian apersepsi, pemberian motivasi dan penyampaian tujuan pembelajaran, kemudian dilakukan pembagian kelompok yang heterogen. Dalam proses pembelajaran di kelas ini, siswa dibagi menjadi 5 kelompok dengan tiap kelompok beranggotakan 5 orang siswa. Kemudian pada setiap kelompok diberikan bahan ajar dan LKSuntuk dikerjakan, masingmasing anggota kelompok bertangung jawab pada satu soal. Kemudian yang mendapat soal atau nasalah yang sama membentuk kelompok baru yang disebut kelompok ahlli. Pada tahap ini, siswa diberikan pengarahan dan bimbingan melalui penjelasan atau pertanyaan yang mengarah pada penyelesaian masalah bila diminta langsung oleh siswa dengan memanfaatkan media pembelajaran. Setelah semuaselesai dari kelompok ahli kemudian kembali ke kelompok asal untuk menjelaskan ke kelompok asalnya sesuai dengan waktu yang ditetapkan, beberapa siswa dipilih mewakili kelompoknya tampil di depan kelas untuk mempresentasekan hasil kerja kelompoknya untuk ditanggapi oleh kelompok lain. Jika ada jawaban siswa yang keliru maka diberikan bantuan untuk mengambil kesimpulan alternatif jawaban yang benar dari hasil pemecahan masalah yang dibuat masing-masing kelompok. Diakhir pertemuan, siswa membuat kesimpulan dari materi yang telah dipelajari.

Pada awal pelaksanaan perlakuan pada kelompok eksperimen mengalami sedikit hambatan. Siswa membutuhkan waktu untuk menyesuaikan diri dengan model pembelajaran yang baru diterapkan di kelas, terutama pada 
saat pembentukan kelompok, sehingga proses ini cukup menyita waktu pembelajaran. Siswa yang tidak terbiasa dengan pembentukkan kelompok belajar, awalnya kurang antusias dalam proses pembelajaran ini. Beberapa siswa menunjukkan sikap yang kurang bekerjasama dalam kelompok, sehingga tidak semua siswa aktif dalam kelompok belajar pada saat proses pembelajaran berlangsung. Hal ini mengakibatkan proses penyerapan materi pembelajaran oleh siswa kurang maksimal. Perlahan-lahan, hambatan-hambatan yang terjadi dapat diatasi dan diminimalisir. Walaupun dibeberapa pertemuan berikutnya, masih ada beberapa komponen komponen model pembelajaran Jigsaw yang tidak terlaksana. Siswa dikontrol dan diarahkan dengan baik, sehingga siswa yang tadinya kurang antusias, merasa senang bekerja sama dalam kelompoknya.

Pada pertemuan ketiga sampai keenam persentasi keaktifan siswa mengalami penurunan secara berturut-turut persentasinya senilai $79,54 \%$, $75 \%$, dan 79,54\%. Keadaan ini disebabkan keadaan siswa sulit memahami masalah didalam LKS sehingga peneliti membimbing keseluruhan kelompok dengan alokasi waktu yang melebihi batasan sehingga berdampak pada proses akhir pembelajaran yaitu meyimpulkan materi, siswa tidak sempat lagi menyimpulkan materi. Pada pembelajaran ketuju dan kedelapan perolehan persentase keaktifan siswa berdasarkan lembar observasi meningkat kembali yaitu sebesar 86,36\%yang berarti bahwa keaktifan siswa pada pertemuan pertama tergolong sangat baik. Pada pertemuan ketuju dan kedelapan, peneliti lebih memperhatikan kekurangan-kekurangan pada pertemuan sebelumnya Secara keseluruhan tingkat keaktifan siswa yang diajar dengan model pembelajaran kooperatif tipe Jigsaw terintrepetasi baik dengan rata-rata keaktifan mencapai $(81,81 \%+81,81 \%+79,54 \%+75 \%+$ $77,27 \%+79,54 \%+86,36 \%+86,36 \%) / 8=$ $80,96 \%$. Dengan kata lain, salah satu kriteria kefektifan dalam proses pembelajaran terpenuhi.

$$
\text { Data kemampuan pemecahan }
$$

masalahmatematik diperoleh melalui tes kemampuan pemecahan masalahmatematik (KPMM). Tes tersebut diberikan kepada siswa kelas eksperimen dan kelas kontrol, sebelum perlakuan (pretest) dan setelah perlakuan (posttest). Setelah dilaksanakan pembelajaran pada kelas eksperimen dengan menggunakan model pembelajaran kooperatif tipe Jigsaw dan pada kelas kontrol dengan menggunakan model pembelajaran konvensional.

Berdasarkan hasil analisis deskriptif dari data yang diperoleh melalui Posstest kemampuan pemecahan masalah matematik siswa yang diujikan pada kelas eksperimen diperoleh rata-rata sebesar 71,92 lebih tinggi dari nilai rata-rata yang diperoleh siswa kelas kontrol sebesar 57,60. Hal ini mengindikasikan dari segi rata-rata hasil posttest, kelas yang diajar dengan model pembelajaran kooperatif tipe Jigsaw lebih tinggi dibandingkan dengan kelas yang diajar dengan model pembelajaran konvensioanal. Dari segi keragaman data (varians), kelas eksperimen dengan nilai varians 100,493 dan kelas kontrol dengan nilai varians 84,667 . Nilai varians tersebut menunjukan bahwa data hasil posstest kelas eksperimen lebih beragam daripada kelas kontrol. Median (nilai tengah) dari posstest kelas eksperimen adalah 74 sedangkan median kelas kontrol yaitu 58. Nilai yang paling sering muncul (modus) dari hasil posstest kelas eksperimen adalah 70 , sedangkan nilai yang sering muncul (modus) pada kelas kontrol adalah 52,5. Hasil analisi deskriptif juga menunjukan bahwa terdapat 22 siswa atau $88 \%$ siswa yang peningkatan kriteria sedang sampai tinggi pada kelas eksperimen dan hanya terdapat 18 siswa atau $68 \%$ siswa yang peningkatan kriteria sedang sampai tinggi pada kelas kontrol. Berdasarkan hasil analisis tersebut, kriteria kefektivan kedua pembelajaran ditinjau dari jumlah siswa yang mengalami peningkatan normalized-gain terhadap kemampuan pemecahan masalah matematik siswa pada kategori sedang sampai tinggi pada kelas eksperimen terpenuhi.

Berdasarkan hasil uji hipotesis untuk melihat baik tidaknya penerapan model pembelajaran kooperatif tipe Jigsaw dibandingkan model pembelajaran konvensioanal dalam meningkatkan kemampuan pemecahan masalah matematik siswa, diperoleh bahwa penerapan model pembelajran kooperatif tipe Jigsaw lebih baik dibandingkan model pembelajaran konvensioanal dalam meningkatkan kemampuan pemecahan masalah matematik siswa. Hal ini didasarkan pada nilai signifikansi independent sample t-test lebih kecil dari $0,05,(0,00<\propto=0,05)$, yang berarti $\mathrm{H}_{0}$ ditolak. 
Merujuk pada kriteria keefektifan: (1) Rekapitulasi rata-rata persentase siswa yang aktif pada pembelajaran dengan penerapan model pembelajaran koperatif tipe Jigsaw mencapai $75 \%$, (2) terdapat $75 \%$ siswa mengalami normalized-gain terhadap kemampuan pemecahan masalah matematik siswa pada kategori sedang sampai tinggi dan (3) model pembelajaran kooperatif tipe Jigsaw lebih baik dibandingkan dengan model pembelajaran konvensional dalam meningkatkan kemampuan pemecahan masalah matematik siswa. Karena semua kriteria kefektivan terpenuhi maka dinyatakan bahwa penerapan model pembelajaran koopertaif tipe Jigsaw lebih efektif dibandingkan model pembelajaran konvensional dalam meningkatkan kemampuan pemecahan masalah matematik siswa. Karena semua kriteria kefektivan terpenuhi maka dinyatakan bahwa penerapan model pembelajaran koopertaif tipe Jigsaw lebih efektif dibandingkan model pembelajaran konvensional dalam meningkatkan kemampuan pemecahan masalah matematik siswa.

\section{Simpulan dan Saran}

\section{Simpulan}

Berdasarkan hasil penelitian dan pembahasan, maka dapat ditarik beberapa kesimpulan, yaitu sebagai berikut :

1. Proses pembelajaran dengan menggunakan model pembelajaran kooperatif tipe Jigsaw pada kelas VIII SMP Negeri 14 Kendari terkategori baik. Secara keseluruhan persentase tingkat keterlaksanaan pembelajaran oleh guru pada 8 kali pertemuan berturut-turut adalah $76,92 \%$, $92,30 \%, 84,61 \%, 76,92 \%, 92,30 \%, 92,30 \%$, $92,30 \%$, dan $92,30 \%$. Persentase ini terkategori baik dengan rata-rata persentase keterlaksanaan pembelajaran dengan model pembelajaran kooperatif tipe Jigsawadalah $87,49 \%$. Sedangkan persentase tingkat keaktifan siswa pada 8 kali pertemuan berturut-turut adalah $81,81 \%, 81,81 \%$, $79,54 \%, 75 \%, 77,27 \%, 79,54 \%, 86,36 \%$ dan $86,36 \%$ dengan rata-rata persentase keaktifan siswa yang mengikuti pembelajaran dengan model pembelajaran kooperatif tipe Jigsaw adalah 80,96\%.

2. Kemampuan pemecahan masalah matematika siswa kelas VIII 1 SMP Negeri
14 Kendari yang diajar dengan menggunakan model pembelajaran kooperatif tipe Jigsaw pada pokok bahasan kubus, balok, prisma dan limas diperoleh nilai rata-rata yaitu 71,92 , standar deviasi 10,02 , varians 100,493 , median 74 , modus 70 , nilai minimum 34 , nilai maiksimum 84 dan diperoleh data siswa yang memiliki peningkatan kemampuan pemecahan masalah matematik siswa tergolong kategori rendah sebnyak 3 siswa atau $12 \%$, kategori sedang sebanyak 13 siswa atau $52 \%$, dan yang tergolong kategori tinggi sebanyak 9 siswa atau $36 \%$.

3. Kemampuan pemecahan masalah matematika siswa kelas VIII ${ }_{1}$ SMP Negeri 14 Kendari yang diajar dengan menggunakan model konvensional, pada pokok bahasan kubus, balok, prisma dan limas diperoleh nilai rata-rata yaitu 57,60, standar deviasi 9,20, varians 84,667 , median 58 , modus 52, nilai minimum 34 , nilai maksimum 72 dan diperoleh data siswa yang memiliki peningkatan kemampuan pemecahan masalah matematik siswa tergolong kategori rendah sebanyak 7 siswa atau $28 \%$, kategori sedang 12 siswa atau $48 \%$ dan yang tergolong kategori tinggi sebanyak 6 siswa atau 24\%.

4. Modelpembelajaran koperatif tipe Jigsaw lebih efektifdibandingkanmodel pembelajaran konvensional pada pokok bahasan kubus, balok, prisma dan limasdalam meningkatkan kemampuan pemecahan masalah matematik siswa kelas VIII SMP Negeri 14 Kendari.

\section{Saran}

Berdasarkan kesimpulan yang diperoleh dalam penelitian ini, maka peneliti memberikan saran-saran seperti berikut ini :

1. Modelpembelajaran koperatif tipe Jigsawsebaiknya dapat digunakan dalam pembelajaran agar siswa dapat lebih berpartisispasi pada pembelajaran dan lebih bertanggung jawab dalam mengerjakan soal yang diberikan dan juga dalam meningkatkan kemampuan pemecahan masalah matematik siswa.

2. Guru sebaiknya selalu mencari referensi dari berbagai sumber untuk mengembangkan bahan ajar maupun LKS yang berkaitan dengan permasalahan-permasalahan yang 
terjadi dalam kehidupan sehari-hari, agar kemampuan pemecahan masalah matematik siswa benar-benar dapat dimaksimalkan.

3. Dalam menggunakan model pembelajaran kooperatif tipe Jigsaw guru harus dapat memilih tenaga ahli secara tepat, kemudian memonitor kinerja siswa dalam menjelaskannya kepada kelompok asalnya masing-masing.

4. Dalam menggunakan model pembelajaran kooperatif tipe Jigsaw guru harus pandai menciptakan suasana kelas yang menyenangkan dan menantang agar siswa tidak merasa bosan dalam pembelajaran dan siswa yang cerdas tertantang untuk mengikuti diskusi.

\section{Daftar Pustaka}

Abidin, Yunus. (2014). Desain Sistem Pembelajaran Dalam Kontesktual Kurikulum 2013. PT Refika Aditama. Bandung

Anisa, Witri Nur (2014). Peningkatan Kemampuan Pemecahan Masalah Dan Komunikasi Matematik Melalui Pembelajaran Pendidikan Matematika Realistik Untuk Siswa SMP Negeri Di Kabupaten Garut. Jurnal pendidikan Dan Keguruan. Vol.1 No.1.
Arikunto, Suharsimi. (2008). Dasar-Dasar Evaluasi Pendidikan. Jakarta: Bumi Angkasa.

Daryanto. (2013). Inovasi Pembelajaran Efektif. Yrama Widya. Bandung.

Kurniasih, I., dan Sani B. (2015). Ragam Pengembangan Media Pembelajaran. Kata Pena.

Ngalimun. (2012). Strategi dan Model Pembelajaran. Aswaja Pressindo. Banjarmasin.

Nurhadi. (2003). Kontekstual dan Penerapannya dalam KBK. Malang: Universitas Negeri Malang.

Shoim, Aris. (2016). 68 Model Pembelajaran Inovatif Dalam Kurikulum 2013. Yogyakata: Ar-Ruzz Media

Sudjana. (2002). Metoda Statistika. Bandung: Tarsito.

Sugiman. (2009). Kemampuan Pemecahan Masalah Matematik Siswa SMP: Problematika Dengan Cara Melatihkannya.

Wardani, Asizah K (2014). Kemampuan Pemecahan Masalah Berdasarkan Perbedaan Jenis Kelamin. Jurnal Pendidikan Matematika STKIP PGRI Sidoarjo. Vol 2, No 1 Maret 2014. 